\title{
Effect Of Nursing Compliance In Washing Hand To Phlebitis Physical Events In Graha Room Hita Husada dr Iskak Tulungagung Hospital
}

\author{
Aprin Rusmawati ${ }^{1}$, Dedi Eko Subekti ${ }^{2}$, Heri Saputro ${ }^{3}$ \\ ${ }^{1,3}$ STIKes Surya Mitra Husada Kediri \\ ${ }^{2}$ RSUD dr Iskak Tulungagung \\ Corresponding author : akbaraprin@gmail.com
}

\begin{abstract}
Bacground: Compliance of nurses in implementing a fixed procedure of nursing actions, including hand washing procedures, became one of the determinants of the success of prevention of nosocomial infections. Noncompliance of nurses in hand washing may lead to an increase in the incidence of phlebitis.

Purpose: The influence of nurse compliance in hand washing of phlebitis incidence rate in Graha Hita Husada Room Dr Iskak Tulungagung Hospital.

Method: The design of this study was observational with cross-sectional design with population All the nurses in Graha Hita Room Dr. Iskak Tulungagung Hospital number of 54 nurses. The sample is part of population that is 48 respondents with sampling technique by Simple random sampling. The data that have been collected is processed by Linear Regression statistic test with significance $\alpha=0,05$.

Result: The results showed that most of the respondents had compliance with handwashing compliance, ie 38 respondents $(79.2 \%)$ and most of the respondents did not experience phlebitis incidence, ie 34 respondents (70.8\%).

Result of analysis of Linear Regression test got value $p$-value $=0,000(<0,05)$ with value of R Square 0,639 which means reject $\mathrm{H} 0$ and accept $\mathrm{H} 1$ so that there is relation of nurse compliance in hand washing with number of phlebitis incident in Graha Hita Husada Room dr Iskak Tulungagung Hospital.

Conclusion: From the results of this study prove the compliance of nurses in hand washing by applying six steps of hand washing and five moments hand washing correctly and accurately able to prevent the incidence of phlebitis.
\end{abstract}

Keywords: Compliance, Hand washing, Phlebitis

Received: February 03, 2018; Revised February 24, 2018; Accepted March 10, 2018

How to Cite: Rusmawati, A., Subekti, D.E., \& Saputro, H. (2018). Effect Of Nursing Compliance In Washing Hand To Phlebitis Physical Events In Graha Room Hita Husada dr Iskak Tulungagung Hospital. Journal Of Nursing Practice. 1(2). 60-65

The Journal of Nursing Practice, its website, and the articles published there in are licensed under a Creative Commons AttributionNonCommercial-ShareAlike 4.0 International License. 


\section{BACKGROUND}

Hospitals efforts to improve the quality of health services, including services provided by nurses. The nurse is a 24 -hour medical assistant along with the hospitalized patient. The role of the nurse is very large in the process of healing the patient. Nurses are required to have the knowledge, skills and good attitude during caring for the patient. Compliance of nurses in implementing a fixed procedure of nursing actions, including hand washing procedures, became one of the determinants of the success of prevention of nosocomial infections.

The level of nurse compliance in handwashing in the United States is still around $50 \%$, in Australia still around 65\%. Similarly, handwashing program since 2008 is proclaimed at Cipto Mangunkusumo Hospital (RSCM) but nurse compliance is only about $60 \%$. It was serious challenge for hospital infection control teams to promote handwashing programs. 2

Nosocomial infections cause 1.4 million deaths every day worldwide. 3 The incidence of nosocomial infections has been one of the benchmarks for hospital service quality. The results of Handoyo's research, et al (2006) phlebitis incidence in hospital surgery wards Prof.Dr. Margono Soekardjo Purwokerto at 31.7\%. Each day found an average of 2-4 patients with phlebitis. Treating phlebitis becomes very important because if not treated it can lead to sepsis.

The incidence of infection in Indonesia associated with health care type or type of hospital is very diverse. A study conducted by the Ministry of Health of the Republic of Indonesia in 2007 obtained data on the proportion of infections related to health services in government hospitals with 55.1\%, while for private hospitals with $35.7 \%$. ABRI Hospital with $9.1 \%$. From the data of the PPI Committee in Dr. Iskak Tulungagung hospital in September 2016 the incidence of HAIs of $0.3 \%$. Based on preliminary studies conducted by researchers on December 31, 2016, known phlebitis incidence rate in Graha Hita Room reached $13.9 \%$. This shows that the phlebitis incidence rate in Graha Hita Room is still very high.

Microorganisms have several ways of transmission to help facilitate the transfer of an agent from a reservoir to a vulnerable host. Mechanism of transmission of infection through direct, indirect, and airborne transmission. During medical care, the hands of healthcare workers often come into contact with patients. Thus, the hands of the clinician are the most common means for transmission of infection. Transmission through this route is more common than vector, congenital or direct and indirect contacts.

Hand washing is the most important action and the only way to prevent the onset of disease. Hand washing is a process that mechanically removes dirt and debris from the skin of the hands using ordinary soap and water. Hand washing can also be done by using antiseptic or antimicrobial agents. A frequently used antiseptic agent is an antiseptic handrub or alcohol-based handrub. The use of an antiseptic handrub for clean hands is more effective at killing resident flora and transient flora than washing hands with antiseptic soap or plain soap and water.

Complete hand washing with adequate amounts of water and soap can remove up to $90 \%$ of the temporary flora. Disinfection with alcohol is used to kill microorganisms and contaminants.6 Increase patient resistance to infection, including nutritional status and susceptibility to infection in an effort to suppress infection transmission.

Failure in hand washing is triggered by limited handwashing facilities, such as sinks, paper towels, hand dryers and antiseptic liquids. However, when there are facilities, the next obstacle is the lack of awareness of the health worker (nurse) to perform 
handwashing procedures so that the nurse does not wash hands thoroughly. WHO complies with the principles of six-step handwashing and five handwashing moments

Noncompliance of nurses in hand washing may lead to an increase in the incidence of phlebitis. Phlebitis is a complication at the time of fluid therapy. The occurrence of phlebitis can be caused by bacterial (infectious), mechanical and chemical non-infectious phlebitis. Infection due to IV therapy is an infection caused by contamination by germs in the cannula and stab wound to enter the cannula, and contamination of germs in infusion fluid. Canal-related infections can occur with or without fever and bacteremia, and may include purulent thromboplebitis, cellulitis and local infection. Infection is usually preceded or accompanied by phlebitis (usually warm and reddish skin over a soft or hard veins). Although it can be caused by infection, phlebitis is usually caused by mechanical or chemical irritation of the cannula or intravenous fluids. The occurrence of infection rates will cause many losses, among others, causing death, either directly or indirectly and make the patient in hospital for longer and more expensive. 8 Infection-related health services can occur to patients, health workers, as well as everyone who comes to the hospital. This infection can be transmitted or acquired through health workers, sick people, and visitors with a career or hospital status.

The solution to be made is that hospitals need to develop infection prevention and control programs. Implementation of Infection Prevention and Control Programme (IPCP), is one form of patient safety program. The purpose of IPCP is to improve the quality of hospital services and other health facilities through infection prevention and control, to protect human health and public health from dangerous infectious diseases, and to reduce the rate of phlebitis.

Given the high risk of occurrence Health Care Associated Infection (HAIs) especially phlebitis, an action should be taken to prevent increased spread of infection. Prevention can be done by evaluation of phlebitis events and also evaluation of nurse compliance in hand washing

\section{OBJECTIVE}

This study was to influence of nurse compliance in hand washing of phlebitis incidence rate in Graha Hita Husada Room Dr Iskak Tulungagung Hospital.

\section{METHODS}

This research was an observational analytic study with the population of all nurses in Graha Hita Room Dr. Iskak Tulungagung hospital number of 54 nurses. A sample of 48 respondents with Simple random sampling and using observational list.

Independent variable used in this research is nurse compliance in hand washing, while the dependent variable used is phlebitis incidence.

\section{RESULTS}

Handwashing Compliance

Most of the respondents had compliance with handwashing compliance 38 respondents $(79.2 \%)$.

Phlebitis incidence

Most of the respondents did not experience phlebitis incidence, is 34 respondents $(70.8 \%)$. Cross tabulation results showed 34 respondents (70.8\%) who had compliance level of handwashing compliance and also did not experience phlebitis. 
Statistical test results by using Linear Regression test:

\begin{tabular}{|c|c|c|c|c|c|c|}
\hline \multicolumn{2}{|c|}{ Model } & Sum of Squares & $\mathrm{df}$ & Mean Square & $\mathrm{F}$ & Sig. \\
\hline 1 & Regression & 6.338 & 1 & 6.338 & 81.458 & $.000^{\mathrm{a}}$ \\
\hline & Residual & 3.579 & 46 & .078 & & \\
\hline & Total & 9.917 & 47 & & & \\
\hline
\end{tabular}

a. Predictors: (Constant), Handwashing Compliance

b. Dependent Variable Phlebitis incidence

Based on the above table it is known that p-value $=0,000(<0.05)$ which means reject $\mathrm{H} 0$ and accept $\mathrm{H} 1$ so that there is influence of nurse compliance in hand washing with phlebitis incidence in Graha Hita Husada Room dr Iskak Tulungagung hospital.

\section{DISCUSSION}

\section{Nursing Compliance In Hand Washing In Graha Hita Husada Room dr. Iskak Tulungagung hospital}

Based on the results of research that has been done is known from 48 respondents, most of the respondents have compliance handwashing obedient, that is 38 respondents (79.2\%). This is supported by cross-tabulation data of respondent's characteristic with handwashing compliance variable, in which obedient handwashing compliance experienced by respondents aged 31-40 years and age 41-50 years ie 15 respondents $(31.2 \%)$, female 21 respondents $(43,8 \%)$, have nursing DIII education that is 23 respondents $(47,9 \%)$ and have worked for 6-10 year that is 20 respondent $(41,7 \%)$. Menurut Smet (1994) yang dikutip oleh Emaliyawati (2013), obedience is the degree to which a person performs a way or behaves according to what is suggested or charged to it. Compliance is part of the individual's behavior to obey or obey something. Obedience is obedient, obedient, obedient to command, rule, discipline. Factors affecting the implementation of nurse hand hygiene include age, education level, level of knowledge, length of service, availability of hand washing facilities, patient condition and hospital policy. ${ }^{11}$

The results showed that most nurses were adherent in hand washing based on 5 handwashing moments prior to contact with the patient, prior to aseptic procedure, after exposure to body fluids, after contact with the patient and after contact with the patient's environment. This is certainly supported by the characteristics of respondents, where most respondents aged 31-40 years and age 41-50 years, female sex, educated DIII nursing and have a working period of 6-10 years.

In this study found the respondents who are not obedient in doing hand washing with disobeying the five moments of hand washing. This is due to lack of awareness of the nurse who causes less compliance nurse to wash hands. Nurses working in hospitals have different characters and vary greatly both level of education, age, employment, and level of knowledge. Differences of these characteristics will certainly affect the mastery of science, skills, and professional attitude of a nurse in performing its role. Some experts as stated by Smet, said that compliance is influenced by internal factors and external factors. Internal factors that influence compliance can be none other than the characteristics of the nurse itself. This is why there are still nurses who do not obey the implementation of hand washing.

\section{Phlebitis incidents in Graha Hita Husada Room dr. Iskak Tulungagung hospital}


Based on the results of research that has been done is known from 48 respondents, most of the respondents did not experience phlebitis, ie 34 respondents $(70.8 \%)$. This is supported by cross-tabulation data of respondent's characteristic with phlebitis incidence variable, where the result of non phlebitis research is experienced by respondents aged 31 40 years, ie 15 respondents $(31.2 \%)$, female sex is 19 respondents $(39.6 \%)$, educated by DIII that is 21 respondents $(43,8 \%)$ and has worked for 6-10 year 17 respondents $(35,4 \%)$.

Plebitis is defined as venous inflammation caused by both mechanical, chemical, and bacterial irritation. Plebitis is characterized by the presence of red and warm areas around intravenous or venous fitting, pain and swelling Plebitis is caused by mechanical factors, chemical factors and bacterial factors including poor handwashing techniques, failure to inspect damaged equipment, leaky or torn wrapping invites bacteria, poor aseptic techniques, poor cannula-mounting techniques, cannula installed too long and places injection rarely in visual inspection. ${ }^{11}$

Based on the results of the study, it is known that most of the respondents did not experience phlebitis incidence. This is because in the installation of infusion, the nurse has done the installation of infusion in accordance with the procedure (SOP) that has been established, including hand washing procedures with six steps five moments. Based on the results of this study known phlebitis incidence rate in Graha Hita Husada room is $29.2 \%$. This suggests that there is still phlebitis occurrence in the chamber although most patients do not experience phlebitis. This can be caused by the existence of nurses who are less adhere to hand wash with six steps and five moments of hand washing so that there is transmission of microorganisms to the intravenous needle piercing area. Other causes of phlebitis can also be caused by mechanical factors and chemical factors not examined in this study but may affect the results of this study so that it can cause phlebitis.

\section{Influence of Nurses Compliance In Handwashing With Phlebitis Incidents In Graha Hita Husada Room Dr. Iskak Tulungagung hospital}

Based on the cross-tabulation between the variables, it was found that there were 34 respondents $(70.8 \%)$ who had compliance level of handwashing and did not experience phlebitis. In addition there are also 4 respondents $(8.3 \%)$ who wash their hands obediently but still experienced phlebitis, 10 respondents $(20.8 \%)$ respondents who did not obey hand washing and also experienced phlebitis. Based on the result of statistic test of linear regression with significance level $\alpha=0.05$, has $\mathrm{p}$-value $=0,000(<0,05)$ with $\mathrm{R}$ Square 0,639 which means reject $\mathrm{H} 0$ and accept $\mathrm{H} 1$ so that there is influence of nurse compliance in hand washing with phlebitis at Graha Hita Husada Dr Iskak Tulungagung Hospital.

Compliance is the basic capital a person behaves. According to Kelmen and Emaliyawati (2010) explained that changes in attitudes and behavior of individuals starting with the process of compliance, identification, and the last stage of internalization. At the beginning the individual obeys the advice / instruction without willingness to perform such acts and often because he wants to avoid punishment if he is disobedient, or to get the reward promised if he obeys the advice. This stage is called compliance stage. Usually the changes that occur at this stage is temporary, meaning that the action was done dive there is still supervision.

Intravenous therapy can not be separated from complications. Complications that can be obtained from intravenous therapy are systemic complications and local complications. Systemic complications are less common but often more serious than local complications such as circulatory overload, air embolism and infection. Local 
complications of intravenous therapy include infiltration, phlebitis, thrombophlebitis, hematoma, and extravasation. Phlebitis is inflammation of the veins caused by catheters or chemical irritants of additives and drugs administered intravenously. ${ }^{7}$

The results showed that there was a significant effect of handwashing compliance with phlebitis occurrence, and this was consistent with existing theories that with proper handwashing corresponding to six-step and five handwashing moments could prevent phlebitis in patients. The existence of this effect is also reinforced by the results of research that can be seen on cross tabulation between hand compliance compliance variable with phlebitis incidence. In this study, it was found that nurse compliance in applying six step five handwashing moment was directly proportional to phlebitis occurrence so that most of the respondents did not have phlebitis, and in disobedient nurses in applying six step five handwashing moment will result in phlebitis incidence.

\section{REFERENCES}

Menteri Kesehatan Republik Indonesia. 2011. Permenkes no 1691/ Menkes/per.VIII.. Tentang Keselamatan Pasien rumah Sakit.

Susiati. 2013. Panduan Praktik Keperawatan Nosokomial Cetakan ke I. Yogyakarta : Citra Aji Parama

WHO. 2012. World alliance of patient safety and WHO Guidelines on hand hygiene in health care anvanced draft. From; www.who. Int/patient safety. Diakses tanggal 2o Desember 2016.

Brunner and Suddarth. 2012. Keperawatan Medikal Bedah Edisi 8 Volume 2. Jakarta : EGC.

Depkes RI. 2013. Cuci Tangan Pakai Sabun Dapat Mencegah Berbagai Penyakit. From http://www. Depkes.go.id. Diakses tanggal 1 januari 2017.

Pruss, et al. 2015. Infection Control in the Hospital second edition.

Potter \& Perry. 2013. Buku Saku Ketrampilan Dan Prosedur Dasar. Jakarta : EGC.

Darmadi. 2013. Infeksi Nosokomial, Problematika dan Pengendaliannya. Jakarta : Salemba Medika.

CDC. 2012. Clean your hands: a simple way to prevent infection. Bersumber : : digilib.ampl.or.id/detail/detail.php?row=2\&tp=artikel\&ktg=sanitasi\&kd_linl=kode =257-16. (Diakses tanggal 24 Desember 2016).

Kemenkes. 2014. Pedoman Teknis Penilaian Kinerja Individu Direktur Utama Rumah Sakit dan Kepala Balai. Jakarta : Direj Bina Upaya Kesehatan.

Sax, H, et al. 2012. Infusion Nursing Standart Of Practice. 